\title{
From Pakatan Harapan to Perikatan Nasional: A Missed Opportunity for Reforms for East Malaysia?
}

By Anantha Raman Govindasamy

\section{EXECUTIVE SUMMARY}

- The Malaysia Agreement 1963 (MA63) brought together Peninsular Malaya with the East Malaysian states of Sabah and Sarawak. This Agreement afforded certain rights and obligations to these two states, notably in areas such as religion and language, financial autonomy, immigration, judicial autonomy, and finance and tax issues.

- However, since the signing of this foundational treaty, East Malaysians have become discontented. Key frustrations include a gradual erosion of the stipulated privileges by the federal government, persistent underdevelopment, as well as the perceived unequal distribution of petroleum revenue earned from these states.

- When Pakatan Harapan came to power in 2018, there were expectations from Sabah and Sarawak that the new administration would be committed to the restoration of East Malaysia's special position within the Malaysian Federation.

- In order to address long-standing tensions, Pakatan Harapan established a Special Cabinet Committee on MA63 to look for new ways of restoring East Malaysia's prerogatives.

- The Special Cabinet Committee managed to resolve seventeen out of twenty-one issues pertaining to the economy, finance and the judiciary. However, the most complex issues pertaining to the sharing of oil revenue were outstanding. One key outcome was that the Committee proposed a constitutional amendment to recognize Sabah, Sarawak and Peninsular Malaysia as equal partners in the Federation. 
- However, the proposed amendment did not garner the necessary two-thirds majority in parliament. A bloc of parliamentarians allied with the Gabungan Parti Sarawak - a coalition of Sarawak-based parties formerly aligned with ousted national coalition Barisan Nasional-abstained from voting.

- Since the advent of the Perikatan Nasional administration, the broader issue of East Malaysian rights has received little attention. It is likely that, rather than seeking to address the fundamental tensions between the Peninsula and East Malaysia, the current administration will seek to offer targeted benefits to elites from the region. 


\section{From Pakatan Harapan to Perikatan Nasional: A Missed Opportunity for Reforms for East Malaysia?}

By Anantha Raman Govindasamy ${ }^{1}$

\section{INTRODUCTION}

Sabah and Sarawak formed the Malaysian Federation together with Malaya and Singapore in 1963. Instrumental to the formation of the new Federation was an international treaty called the Malaysia Agreement 1963, signed in London by the British and Malayan Federation governments, and political representatives from Sabah, Sarawak and Singapore. The Malaysian Agreement guaranteed a special position as demanded by the East Malaysian political elites in the areas of religion and language, finance and tax, judiciary and immigration.

In the early stages, there was huge expectation that joining the Malaysian Federation would elevate East Malaysia's economic growth and bring adequate development to these vastly rural states. Substantial oil and gas discoveries in the early 1970s further prompted demands for meaningful economic development in Sabah and Sarawak.

The ruling federal government under Barisan Nasional (BN), while acknowledging the lagging economic conditions in East Malaysia, failed to meet expected levels of development and poverty reduction. At the same time, Peninsular Malaysia was systematically developed

\footnotetext{
${ }^{1}$ Anantha Raman Govindasamy is Associate Professor at the Centre for the Promotion of Knowledge and Language Learning (CPKLL), Universiti Malaysia Sabah (UMS) and Visiting Research Fellow at the ISEAS - Yusof Ishak Institute, Singapore. The author would like to express his gratitude to Francis Hutchinson and Lee Hwok Aun for their useful comments and suggestions on the initial draft.
} 
as one of the world's fast-growing economies. Sabah's and Sarawak's special position in the federation, especially various safeguards related to economic well-being, were eroded over time through legislative amendment and political manoeuvring that strengthened Peninsular power over East Malaysia.

The unprecedented win for Pakatan Harapan (PH) in the 2018 Malaysian General Election, however, revitalized demands for the restoration of East Malaysia's special position in the Malaysian Federation. A Special Cabinet Committee on MA63 was created and headed by the Prime Minister to oversee the restoration of the spirit of the initial Malaysia Agreement. These efforts were spearheaded by the PH-aligned Sabah state government, helmed by Chief Minister Shafie Apdal. By 2019, this Committee had amicably resolved seventeen out of twenty-one matters tabled by the East Malaysian states. It even proposed a constitutional amendment to recognize Sabah, Sarawak and Peninsular Malaysia as equal partners in the Malaysian Federation.

This initiative unfortunately failed to get the required two-thirds parliamentary majority. The collapse of PH in February-March 2020 and the rise of a Perikatan Nasional (PN) federal administration created uncertainty regarding the proposed restoration of East Malaysian rights. In fact, the previous report written by the MA63 Special Cabinet committee has been placed under the Official Secrets Act (OSA) by PN.

This study traces political developments which occurred in East Malaysia under PH and examines prospects for the restoration of East Malaysia's special position under PN. It starts by first surveying the political dynamics within East Malaysia with a focus on understanding recent unhappiness regarding Sabah and Sarawak's special position. This sets the context for a focus on the formation of the PH government in 2018 until the declaration of a state of Emergency by the PN government on 12 January 2021.

By drawing data from seven key informant interviews and five focus group discussions with East Malaysian politicians and senior state civil servants, as well as members of East Malaysian-based political parties, this study argues that under the PH federal administration, Malaysia missed a golden opportunity to restore Sabah and Sarawak's special position. Moreover, PN, while verbally committing to MA63, 
demonstrates less purpose and vigour compared to $\mathrm{PH}$. The cause has become even less of a priority as the fragile federal government coalition grapples with the COVID-19 pandemic.

\section{BACKGROUND}

Sabah (formerly known as North Borneo) and Sarawak decided to join and form the Malaysian Federation together with the Malayan Federation and Singapore in 1963. Prior to this, Sabah was ruled by the British North Borneo Chartered Company, and Sarawak was under the Brooke Dynasty. Both states became British Crown Colonies after the Second World War.

In the late 1950s, political elites in Sabah and Sarawak expressed a desire to be independent states, including being part of a larger federation. To facilitate this desire, the British created the Cobbold Commission to carry out a fact-finding exercise and determine the possibility of these states coming together to form a federation with Malaya.

After having various discussions with the people of Sabah and Sarawak, the Cobbold Commission found that most people of these states were in favour of joining a federation with Malaya, if they were given a special position to safeguard certain rights. ${ }^{2}$ These demands were stipulated in two separate documents, called 20 Points for Sabah and 18 Points for Sarawak. In response, an Inter-Governmental Committee was set up consisting of the British, the Malayan government, Sabah and Sarawak to harmonize the terms and conditions and preserve the East Malaysian states' interest. The Malaysian Agreement, an international treaty, was signed in London by the British, Malaya, North Borneo (Sabah), Sarawak and Singapore in $1963 .^{3}$

\footnotetext{
2 Mugunthan Vanar, "Historian Should Use Cobbold Commission Report", The Star, 10 October 2018, https://www.thestar.com.my/metro/metro-news/ 2018/10/10/wrong-documents-were-cited-historian-should-have-used-cobboldcommission-report-in-his-argument-says (accessed 23 April 2021).

3 The Malaysian Agreement 1963, https:/treaties.un.org/doc/publication/unts/ volume\%20750/volume-750-i-10760-english.pdf (accessed 4 April 2021).
} 
In line with the Malaysian Agreement, the 1957 Malayan Constitution was amended to include Sabah and Sarawak's special position in the Federal Constitution of Malaysia, in recognition of their co-equal status alongside Peninsular Malaysia, as well as their distinctive identity and economic conditions. ${ }^{4}$

A summary of unique rights afforded the two East Malaysian states is as follows: ${ }^{5}$

- There is no official State religion in Sabah or Sarawak.

- Sabah and Sarawak can use English as their official language, as well as the native languages of the natives of Sabah and Sarawak in the Native Courts or for any native law and custom.

- The consent of the Yang di-Pertua Negeri (Governors) of Sabah and Sarawak is required for constitutional amendments affecting the special position of these states.

- Sabah and Sarawak can control the entry and residence of nonSabahans and non-Sarawakians into their territories.

\footnotetext{
${ }^{4}$ Unlike Peninsular Malaysia which is dominated by the Malay-Muslim ethnic majority, East Malaysia's ethnic demography is more diverse. In Sabah, there are forty-two ethnic groups and nearly 200 subethnic groups. Coastal lowlands are mostly inhabited by the Muslim-bumiputra community-Bajau, BruneianMalay, Bugis, and Suluk. The highlands and interiors are dominated by the nonMuslim bumiputra community, mainly Christians, such as Kadazan, Dusun, Murut, Rungus and Lundayeh. The Chinese are mainly settled in the urban areas of Sabah. Like Sabah, Sarawak ethnic groups are diverse, the Non-Muslim bumiputra are collectively called Dayak and account for nearly 40 per cent of the population. The two biggest ethnic groups within Dayak are Iban and Bidayuh. The Malay and Melanau ethnic groups, mainly Muslims, inhabit coastal and urban areas. The Chinese community mainly dominates urban areas such as Kuching and Miri. K. Ganesan et al., "Environmental Challenges and Traditional Food Practices: The Indigenous Lundayeh of Long Pasia, Sabah, Borneo", ETropic: Electronic Journal of Studies in the Tropics 19, no. 1 (2020), https:// doi.org/10.25120/etropic.19.1.2020.3734 (accessed 15 May 2021).

${ }^{5}$ My Constitution: About Sabah and Sarawak, Malaysian Bar, https://www. malaysianbar.org.my/article/about-us/committees/constitutional-law-committee/ my-constitution-about-sabah-and-sarawak (accessed 21 April 2021).
} 
- Sabah and Sarawak each has separate High Courts from the Peninsula, having jurisdiction over the respective states.

- The Chief Ministers of Sabah and Sarawak must be consulted on who to appoint as Chief Judge of the High Court in Sabah and Sarawak.

- Sabah and Sarawak have sources of revenue and special grants of money from the Federal government that other states in Malaysia do not, and they can also charge their own state sales tax.

- Sabah and Sarawak can raise loans with the consent of Bank Negara Malaysia.

- The legislative assemblies of Sabah and Sarawak have the power to make laws on additional matters which the legislative assemblies of other states do not. These matters include native law and custom, water supplies and services, personal laws relating to marriage, divorce, guardianship and adoption, as well as distribution of water and electricity.

- The Malaysian Parliament has the power to pass legislation on some matters in the state list to ensure that the laws on these matters are the same across West Malaysian states. However, Parliament's power to do this does not extend to Sabah and Sarawak.

- Parliament also has the power to pass laws on matters in the State List to give effect to a National Development Plan. However, if it involves the states of Sabah and Sarawak, the consent of the Yang di-Pertua Negeri (Governors) must be obtained.

- The natives of Sabah and Sarawak enjoy special positions such as quotas or employment in the public service (Borneonization of civil service), scholarships, places in public educational institutions and business permits or licences. ${ }^{6}$

Since the formation of Malaysia in 1963, some of these special provisions have been amended by the relevant state assembly. For instance, the Sabah State constitution was amended to include Islam as the official

6 Shad Saleem Faruqi, "The Malaysia Agreement: Blueprint for Unity in Diversity", https://law.um.edu.my/img/files/UM\%20CLI_\%20MA63\%20 webinar_\%20Blueprint\%20for\%20unity.pdf (accessed 21 April 2021). 
state religion and Malay as the official language. But other constitutional amendments initiated by the federal parliament diluted the array of unique provisions concerning Sabah and Sarawak without their consent.

The most consequential of these was the 1976 amendment of Article 1(2) of the Malaysian Federal Constitution, which downgraded Sabah and Sarawak from being co-equal regions of the Federation along with the Peninsula, to being merely two of thirteen states in the Federation. ${ }^{7}$ This amendment, although it had the majority support of East Malaysian members of parliament, did not get the consent of state governors as stipulated in the Malaysian Agreement. ${ }^{8}$ This receding of Sabah's and Sarawak's political leverage was a precursor to their economic marginalization.

In fact, many believe that economic interest was the main motivation for the federal government to initiate the 1976 constitutional amendment. In 1974, the Petroleum Development Act (PDA) was passed, giving the state-owned oil company Petronas sole ownership over the nation's oil and gas, most of which comes from Sabah and Sarawak's territorial waters. Furthermore, in 2012 the federal government passed the Territorial Sea Act — again without the consent of Sabah and Sarawak — which limits the two Borneo states' jurisdictions over their waters to 3 nautical miles from the coastline, away from most oil and gas fields.

Likewise, the consent of Sabah and Sarawak was not obtained when critical state matters such as tourism was taken over by the federal

\footnotetext{
7 The amendment to Article 1(2) of the Federal Constitution downgraded the status of Sarawak and Sabah from regions to states when it was debated on 12 and 13 July 1976. The amendment was supported by 130 MPs, while four objected. The amendment to Article 1(2) was among 48 amendments made to the Federal Constitution under a Bill tabled by then Prime Minister Datuk Hussein Onn on 12 July 1976 and was passed on 13 July 1976. None of the MPs from Sarawak opposed the Bill covering the amendments. The four MPs who opposed it were Lim Kit Siang, Dr Tan Chee Khoon, Farn Seong Than and Lee Lam Thye from DAP. See more at Jonathan Chia, "All Around Aye for Sabah, Sarawak", Borneo Post, 19 October 2016, https:/www.theborneopost.com/2016/10/19/allround-aye-from-sabah-sarawak/ (accessed 12 December 2020).

${ }^{8}$ Faruqi, "The Malaysia Agreement: Blueprint for Unity in Diversity".
} 
government in 1994. Additionally, the power of state governors to appoint Judicial Commissioners to the High Court of Borneo was handed over to Yang Di-Pertuan Agong and Article 121(1) in the Federal Constitution was amended, thus attenuating the powers of the courts including the High Court of Borneo (since 1994 known as High Court of Sabah and Sarawak). This was done without the consent of state governors as stipulated in the Malaysian Agreement.

Unlike the peninsular states, MA63 also provided unique fiscal privileges to Sabah and Sarawak. These included eight sources of revenue: import and excise duty on petroleum products; export duty on timber and other forest products; royalty on minerals; 30 per cent customs revenue on medicine and health products; state sales tax; state ports and harbours, as well as water supply and revenue from licences connected to water supply. MA63 also entitles Sabah and Sarawak to receive special grants and mandatory financial allocations from the federal government. ${ }^{9}$

But Sabah and Sarawak claimed that most of these terms and conditions involving finance, special grants, and mandatory allocations were not fully honoured by the federal government. For instance, only as recently as 2019 did Sarawak manage to solve the long sales tax dispute with Petronas, when the state received RM2 billion as part of the sales tax settlement. ${ }^{10}$ Sabah is also expecting a similar result as Petronas promised to settle the sales tax of approximately RM1.2 billion. ${ }^{11}$ Sabah and Sarawak also claim that despite the two states currently producing 60 per cent of Malaysia's petroleum worth an estimated RM38 billion

\footnotetext{
${ }^{9}$ Ibid.

10 Mohammad Ahmad Hamdan, "Petronas Has Paid RM2.95b in SST to Sarawak", The Edge Markets, 17 September 2020, https://www.theedgemarkets. com/article/petronas-says-it-has-paid-sarawak-sst-2019 (accessed 23 April 2021).

11 Bernama, "Jeffrey: Sabah to Collect RM1.25 Billion Tax from Petronas", Free Malaysia Today, 7 November 2020, https:/www.freemalaysiatoday.com/ category/nation/2020/11/07/jeffrey-sabah-to-collect-rm1-25-billion-tax-frompetronas/ (accessed 22 April 2021).
} 
in 2017, they each only receive 5 per cent of the revenue. Under the mandatory financial allocation, Sabah is to receive two-fifths (or 40 per cent) of its own net revenue. Sarawak is promised annual grants that would increase from RM3.5 million to RM21 million over four years, but since 1963 this has never been implemented. ${ }^{12}$

Sabah and Sarawak claim that the Borneonization of the civil service had not been properly implemented by the federal government. Under the initial agreement, qualified Sabahans and Sarawakians should be given priority to serve in the federal civil service in these states, including the selection of high-ranking officers. These states argue that the process is too slow, and the federal government still gives priority to West Malaysians in appointing civil servants for positions such as federal administrators, public university chairpersons, Vice Chancellors, and teachers. ${ }^{13}$ For instance, 89 per cent of teachers in Sabah are from West Malaysia and the recruitment of Sabahans into the teaching profession has traditionally been low. ${ }^{14}$

The non-Muslim bumiputra communities feel that the aggressive Islamization policy pushed by the federal government since the 1980s has diluted the native characteristics of Sabah and Sarawak. Although Islam has been accepted as the official religion in the state of Sabah, Sarawak remains without an official state religion and language, and nearly 50 per cent of the East Malaysian population are Christian or other non-Muslim faiths. There is fear that hard-line religious practices from West Malaysia will be introduced in the East Malaysian states, as seen

12 Chen Yih Wen and Johenson Goh, "The Malaysian Agreement Disagreement", The Star, 16 September 2020, https://www.thestar.com.my/ news/nation/2018/09/16/the-malaysia-agreement-disagreement (accessed 22 September 2021).

${ }^{13}$ Jason Santos, "Sabah Leaders Insist Locals Leading UMS", Malaysian Insight, 1 June 2017, https://www.themalaysianinsight.com/s/4103 (accessed 21 April 2021).

${ }^{14}$ Daily Express (Sabah), "Borneonisation Promise Has Been Reneged: Yong", 11 March 2015, http://www.dailyexpress.com.my/news.cfm?NewsID=97812 (accessed 22 April 2021). 
in the recent controversy on the use of the word "Allah" by non-Muslim communities. ${ }^{15}$

MA63 vested Sabah and Sarawak with full control on immigration matters. However, unclear and overlapping jurisdiction between the state and federal government, mainly regarding migration, has caused problems. Of key concern is an influx of illegal immigrants to Sabah. It was reported in 2020 that Sabah's population was 3.9 million, out of which 1.2 million were illegal immigrants. ${ }^{16}$ Moreover, the final report on the Royal Commission of Inquiry (RCI) published in 2014 concluded that "Project IC" (producing Malaysian Identification Cards to illegal immigrants) may have existed. However, the scope of the RCI was limited, resulting in a failure to name the involved parties. ${ }^{17}$

The federal BN administration has wielded substantial influence in East Malaysian politics at pivotal moments through its practices of patronage politics and interference. In fact, the federal administration of the day has played an important role in every major political change in Sarawak and Sabah. The federal government declared a State of Emergency in Sarawak on 15 September 1966 to remove Kalong Ningkan as the Chief Minister of Sarawak. ${ }^{18}$ In Sabah, BN supported Parti BERJAYA headed by Harris Salleh to bring down then Chief Minister Tun Mustapha in

${ }^{15}$ Malay Mail, “'Allah' Ruling Affirms True Meaning of Word for Sarawakian Bumis, Says Yayasan Perpaduan Sarawak", 12 March 2021, https://www. malaymail.com/news/malaysia/2021/03/12/allah-ruling-affirms-true-meaningof-word-for-sarawakian-bumis-says-yayasan/1957132 (accessed 22 April 2021). ${ }^{16}$ Olivia Miwil, "Sabah Tops the List in Number of Illegal Immigrants", New Straits Times, 15 May 2020, https:/www.nst.com.my/news/nation/2020/05/592704/ sabah-tops-list-number-illegal-immigrants (accessed 22 April 2020).

${ }^{17}$ Neil Chan, "No Need for a Second RCI on Illegal Immigrants: Yong", Daily Express, 29 July 2019, https://www.dailyexpress.com.my/news/138557/noneed-for-a-second-rci-on-illegals-yong/ (accessed 21 April 2020).

${ }^{18}$ Borneo Post, "Revisiting 48 Years Leadership", 16 September 2016, http:// www.theborneopost.com/2011/09/16/revisiting-48-years-of-leadership/ (accessed 23 December 2020). 
1976. The BN federal government also orchestrated the downfall of Parti Bersatu Sabah in the 1990s and facilitated the arrival of the United Malays National Organization (UMNO) in Sabah.

Notwithstanding federal government dominance, East Malaysian political elites have also failed to effectively voice concerns regarding the erosion of East Malaysian's special position. The outcome not only strengthened BN's interest but also created a dependent relationship, where the political survival of East Malaysian politicians was largely determined by the federal government in Kuala Lumpur. In fact, the BN-dominated federal government strategy for East Malaysia was based on four principles: accommodate, control, reward, and punish. This approach brought political stability in East Malaysia and, at the same time, BN's interests were safeguarded. East Malaysia's demands for the restoration of its special position in accordance with the 1963 Malaysian Agreement eroded during BN's rule.

The lagging development of East Malaysia has persistently been a sore point, one that East Malaysia's political elites have widely traced to the erosion of prerogatives set out in Malaysia Agreement 1963. Constitutional amendments and political machinations cemented the federal government's control over East Malaysian resources, and arrogated itself a free hand to implement policies that suited its interest.

East Malaysia remains among the most underdeveloped regions in Malaysia. Currently, Sabah is the poorest state in Malaysia, with a poverty rate of 19.5 per cent involving 99,869 households. Five districts, namely Tongod, Pitas, Kota Merudu, Beluran and Telupid, have recorded the highest poverty rate in the country. Sarawak followed closely in third place with a 9 per cent poverty rate involving 56,165 households. ${ }^{19}$ In fact, some argue that Sarawak is a rich state with poor families since it

19 Avila Geraldine, "Sabah Ranks as Malaysia's Poorest State, Again", New Straits Times, 19 September 2020, https://www.nst.com.my/news/ nation/2020/09/625711/sabah-ranks-malaysias-poorest-state-again (accessed 9 December 2020). 
ranks third in number of poor families in Malaysia. ${ }^{20}$ Moreover, literacy rates in Sabah and Sarawak are lagging at 79 per cent and 72 per cent, respectively, while the rest of Peninsular Malaysia had a 97.3 per cent literacy rate in $2010 .{ }^{21}$

\section{PAKATAN HARAPAN: A MIXED BLESSING?}

The loosely cobbled coalition called Pakatan Harapan ( $\mathrm{PH}$ ) came to power in May 2018, as a result of Malaysia's 14th General Election (GE14). It comprised Parti Pribumi Bersatu Malaysia (BERSATU), Parti Keadilan Rakyat (PKR), Democratic Action Party (DAP) and Parti Amanah (Amanah), and was supported by Parti Warisan Sabah (Parti Warisan).

The restoration of East Malaysian's special position was one of the ten main election promises - to be delivered in the first 100 days - that were put forward in PH's GE14 manifesto. ${ }^{22}$ Soon after taking power, the $\mathrm{PH}$ federal government proceeded to deliver on the promised restoration of East Malaysia's prerogatives, with close cooperation from Parti Warisan, PH's coalition partner in Sabah. In fact, Parti Warisan played a crucial role ranging from the formation of a Special Cabinet Committee on Malaysia Agreement 1963 to the attempted constitutional amendments of Article 1(2) of the Malaysian Federal Constitution.

On the other hand, Sarawak led by Gabungan Parti Sarawak (GPS), was playing a neutral game, claiming that more radical changes were needed. GPS's stance lacked cogency, and came across as driven more by political expediency. Based on PH's demonstration of political will and an institutionalized process for MA63, it is difficult to dispute that $\mathrm{PH}$

\footnotetext{
${ }^{20}$ Borneo Post, "Chong: Sarawak a Rich State, With Poor People”, 25 July 2020, https://www.theborneopost.com/2020/07/25/chong-sarawak-a-rich-state-withpoor-people/ (accessed 20 December 2020).

${ }^{21}$ Chen and Goh, "The Malaysian Agreement Disagreement".

${ }^{22}$ Buku Harapan: Membina Negara Memenuhi Harapan, 2018.
} 
was significantly firmer and bolder than the preceding BN administration to which GPS was formally aligned.

This section traces the major political developments and attempted reforms related to East Malaysia under the PH federal administration. It argues that the change of the federal government in 2018 from BN to $\mathrm{PH}$ brought real hope to restore East Malaysia's special position, and changed the dynamics of the state-federal relationship that was once dominated by the federal government's interest in East Malaysian politics. However, PH's collapse cut short those initiatives. Whether PH would have realized the remainder of its agenda is now a counterfactual that cannot be ascertained, although we may assume that initiatives driven by the executive and not requiring bipartisan parliamentary support stood a good chance of being brought to fruition.

\section{Political Developments under Parti Warisan}

In Sabah, following a brief tussle, a Parti Warisan-PH coalition took over the state administration from BN. Initially Musa Aman from UMNO-BN was appointed as the Chief Minister of Sabah with the support from Parti Solidariti Tanah-Airku (STAR) headed by Jeffrey Kitingan. However, a defection from one of the key state BN coalition parties, United Pasokmomogun Kadazandusun Murut Organization (UPKO), along with five state assemblymen, made it possible for the Parti Warisan-PH coalition to claim a majority of state assembly seats and be installed as the Sabah state government. ${ }^{23}$

The Warisan-PH coalition headed by Shafie Apdal, was a multiethnic party with members representing various bumiputra and non-bumiputra groups in Sabah. Other coalition members were DAP, PKR and UPKO. According to Phoong Jin Zhe, the current Sabah state assemblyman for Luyang, and a member of Shafie's state cabinet, only a multiethnic party like Parti Warisan was suitable to represent Sabah's ethnic and religious diversity.

${ }^{23}$ Focus group discussion with senior civil servants from Sabah, 11 January 2021. 
In line with this, the state and federal administration positions were carefully distributed by taking these diversities into account. ${ }^{24} \mathrm{He}$ further noted that Warisan-PH had cordial relations with the Pakatan federal government under Mahathir Mohamad and took the issue of the state's development and the restoration of Sabah's special position seriously. In assessing their main achievements, Phoong maintains that:

in our short time running the Sabah state government, we have managed to develop a comprehensive agricultural policy for Sabah and more importantly we have managed to subdivide native land titles which have been major issues among the rural poor. Also state Warisan leaders like the late Liew [Vui Keong] played an important part in the creation of a Cabinet committee on restoring East Malaysians' rights.

A similar appraisal emerged in a focus group discussion with senior civil servants:

Unlike the previous BN government, the Pakatan Harapan federal government worked closely for political reforms for East Malaysia on the MA63, and the Sabah state government under WarisanPakatan Harapan was practically pushing the state civil servants for immediate reforms especially on issues related to native land ... we were under constant pressure to do reforms ... which was something new to us. ${ }^{25}$

Under Pakatan Harapan, Sabah enjoyed a relatively good relationship with the federal government headed by Mahathir Mohamad. The PH federal government accommodated Shafie Apdal's request to include more political reform-minded leaders from Sabah in the federal cabinet.

\footnotetext{
${ }^{24}$ Interview, Phoong Jin Zhe, a former state minister, 9 December 2020.

${ }^{25}$ Focus group discussion with senior civil servants from Sabah, 19 December 2020 .
} 
This was to ensure a meaningful discussion on the restoration of East Malaysia's special position so that ensuing discussions could be quickly formulated into policies by closely working with the federal government. The appointment of Liew Vui Keong, the permanent Warisan chairperson as the de facto law minister in Mahathir's cabinet, is a clear example that the federal government under $\mathrm{PH}$, at least in the beginning, was serious about MA63-related reforms.

The cohesion of the Sabah state government, and momentum of these reforms, were arguably set back by BERSATU's expansion to East Malaysia, in which Mahathir played an important role. On many occasions, Mahathir argued that there was a need to replace UMNO with another West Malaysian-based national bumiputra party to safeguard East Malaysian rights. Initially, Shafie Apdal, the Warisan president, was against Mahathir's idea of bringing in his party to East Malaysia. But in December 2018, a large number of Sabah-based UMNO parliamentarians and state assemblymen announced that they were leaving UMNO. UMNO's exodus was headed by former party strongman Haji Hajiji Noor. Later, nine assemblymen and five MPs all formerly from UMNO, pledged loyalty to Mahathir Mohamad. In early 2019, Mahathir announced that he had made a deal with Shafie Apdal's Warisan to expand BERSATU to Sabah mainly to accommodate former UMNO lawmakers.

But according to Darell Leiking, the person behind Mahathir's action on the expansion of BERSATU to Sabah was Muhyiddin Yassin. Darell recalled on many occasions that Muhyiddin Yassin had expressed BERSATU's desire to expand in Sabah. BERSATU was to work closely with Warisan-PH to create political stability in Sabah as well as fast-track the reforms which included the restoration of East Malaysia's special position. Darell further noted that Shafie Apdal allowed BERSATU into Sabah following Mahathir's formal proposition which was also driven by respect for the elder statesman. ${ }^{26}$

\footnotetext{
${ }^{26}$ Interview, Darell Leiking, former Minister of International Trade and Industry (a member of the Special Cabinet Committee on MA63), 30 April 2021.
} 
The arrival of BERSATU in Sabah received mixed responses from the state Warisan-PH coalition members. On one hand, the state DAP welcomed BERSATU saying it would strengthen the PH coalition in the state. On the other, Parti Warisan Sabah was against this move, fearing that it would create a parallel to UMNO rule in Sabah.

Yet the expansion of BERSATU in Sabah was inevitable. In fact, in a short span of time, BERSATU Sabah managed to take over the existing UMNO machinery and had systematically built up its members, with many formerly from UMNO. By late 2019, BERSATU Sabah had already established twenty-five divisions statewide. During my focus group discussions with senior state civil servants, they argued that UMNO and BERSATU have had some kind of unwritten agreement to share resources and members. Moreover, UMNO leaders who defected to BERSATU like Haji Hajiji Noor already had strong grassroots support from the Muslim-bumiputra community in Sabah.

BERSATU's relationship with Parti Warisan had been uneasy since the former's establishment in Sabah. Parti Warisan was not keen to accommodate BERSATU members in key positions in the state or federal government. Moreover, there was suspicion among state Warisan-PH coalition members that the creation of BERSATU in Sabah was supported by the UMNO leadership. ${ }^{27}$ In fact, during the state-level Merdeka celebration in 2019, the elected representatives from BERSATU were largely absent, citing they were not invited by the organizer headed by Parti Warisan.

Meanwhile, Sabah opposition political parties such as UMNO, Parti Bersatu Sabah and Parti Solidariti Tanah-Air claimed that Parti Warisan was failing to bring major developments as promised in the election manifesto and, more importantly, argued that Parti Warisan was very much in favour of illegal immigrants. This has been an acerbic

\footnotetext{
${ }^{27}$ Tracy Patrick, "PPBM in Sabah Could Spell Trouble for Warisan", Free Malaysia Today, 15 February 2019, https://www.freemalaysiatoday.com/ category/nation/2019/02/15/ppbm-in-sabah-could-spell-trouble-for-warisansays-analyst/ (accessed 20 December 2020).
} 
debate - especially in non-Muslim bumiputra areas of Sabah. The ruling Parti Warisan denied any policy flexibility for foreigners to gain citizenship under their rule. Indeed, Parti Warisan argued that the current illegal immigrant problems in Sabah were created under previous BN administrations in Sabah.

\section{Sarawak: The Rise of Gabungan Parti Sarawak}

In the case of Sarawak, when Pakatan Harapan took over the federal government from BN in 2018, the state's political situation changed drastically. The Sarawak BN disbanded and the Gabungan Parti Sarawak was established by the former state BN coalition parties-Parti Pesaka Bumiputera Bersatu (PBB), Sarawak United People's Party, Parti Rakyat Sarawak, and Progressive Democratic Party - to consolidate these parties' continuing relevance in the state's politics. The GE14 parliamentary results were sobering for the former $\mathrm{BN}$-aligned parties, who had their parliamentary seats reduced from twenty-five to nineteen at the hands of DAP, PKR and independent candidates. Importantly, besides urban Chinese support, $\mathrm{PH}$ managed to penetrate non-Muslim bumiputra Dayak rural areas which had traditionally been BN strongholds.

The Sarawak BN parties' post-GE14 postures were calculated and expedient. According to Bobby William, president of Parti Bansa Sarawak Baru:

Sarawak BN'S transformation to GPS was a political strategy to show neutrality in politics to engage with Pakatan Federal Government under Mahathir mainly for federal funding. But in reality, GPS was very much with UMNO-BN. GPS leaders were talking about "Sarawakian Nationalism" on the other hand not supporting the proposed constitutional reforms to restore East Malaysians rights mooted by Pakatan Harapan. ${ }^{28}$

${ }^{28}$ Interview, Bobby William, the current president of Parti Bansa Sarawak Baru, 29 January 2021. 
In fact, in the run-up to the 2018 Malaysian General Election, Abang Johari blamed Mahathir for being lazy and not developing Sarawak during his tenure as prime minister of Malaysia. When Mahathir took over as prime minister under Pakatan Rakyat, the Sarawak Chief Minister frequently visited him to mend previous differences. At one point, Mahathir Mohamad was hoping that Sarawak members of parliament from GPS could help PH in its planned constitutional reforms for Malaysia. But according to senior civil servants in Sarawak, "there was a fear among the GPS members when Pakatan Harapan took over the federal government whether it will side-line Sarawak's concerns including the major infrastructure projects such as the Pan-Borneo Highway project." ${ }^{29}$ This view reflects the distrust and antipathy that permeated relations between GPS and PH, particularly due to Mahathir as well as DAP.

As in Sabah, expansion of BERSATU in Sarawak was a matter of concern to the ruling coalition GPS, which felt that Mahathir would be using "federal power" to galvanize support from the state PH mainly in the majority Muslim-bumiputra state constituencies against PBB's Muslim-bumiputra candidates in the state election. The arrival of BERSATU in Sarawak was seen as a clear attempt by PH in Putrajaya to reduce the relevance of Parti Pesaka Bumiputra Bersatu, the main party representing the Muslim-bumiputra community in the state. Since Mahathir announced the creation of the Sarawak chapter of BERSATU, six major divisions of BERSATU have been created in Muslim-bumiputra majority areas in Sentobong, Stampin, Kota Samarahan, Sri Aman and Bintulu. $^{30}$

This rapid expansion of $\mathrm{PH}$ in Sarawak has been a major challenge for GPS headed by Sarawak Chief Minister, Abang Johari Openg, who is from the minority Malay-Melanau community. In the 14th General

\footnotetext{
${ }^{29}$ Focus group discussion with former and current senior civil servants Sarawak, 12 December 2020.

${ }^{30}$ Sharon Ling, "Bersatu Looks to Strengthen Presence in Sarawak", The Star Online, 20 June 2019, https://www.thestar.com.my/news/nation/2019/06/20/ bersatu-looks-to-strengthen-presence-in-sarawak (accessed 20 December 2020).
} 
Election, the state opposition had won twelve parliamentary seats-six of these seats had fourteen state assembly seats; thirteen of these state assembly seats are currently controlled by GPS. ${ }^{31}$ With the state election due in 2021, there is real fear that PH might end the long dominance of PBB and also provide a Dayak Chief minister. This would be the first since Penghulu Tawi Sli in the 1970s. ${ }^{32}$ This factor forced Gabungan Rakyat Sabah to work closely with UMNO and the Pan-Islamic Party of Malaysia (PAS) to oppose various $\mathrm{PH}$ policies in parliament.

\section{THE SPECIAL CABINET COMMITTEE ON MA 63 AND CONSTITUTIONAL AMENDMENT TO ARTICLE 1(2)}

The PH federal government's efforts on the MA63 agenda were significantly driven by Sabah cabinet members, and were felt on the ground in the state. Parti Warisan leaders in the PH federal government, such as the late Liew Vui Keong and Darell Leiking ${ }^{33}$ played an active part in pushing the federal government to establish a proper committee to discuss the restoration of East Malaysian Rights. The formation of a Special Cabinet Committee on the 1963 Malaysian Agreement and the constitutional amendments to Article 1(2) in the Malaysian Constitution were the biggest attempts by the $\mathrm{PH}$ federal government to restore East Malaysia's special position. As noted by Tricia Yeoh (2020), the PH federal government, until it abruptly collapsed in early 2020, was aggressive and serious about restoring East Malaysian rights. Had PH continued in power, it could well have delivered on most of the MA63

\footnotetext{
${ }^{31}$ In 2018, Sarawak only conducted election for parliamentary seats. State election for Sarawak is due in 2021.

${ }^{32}$ Khaire Hisham Aiman, "Shifting Sands Sarawak Put Pressure", The Edge Markets, 21 June 2018, https://www.theedgemarkets.com/article/shifting-sandssarawak-put-pressure-pbb (accessed 20 November 2020).

${ }^{33}$ In an interview with Darell Leiking, he pointed out that Mahathir Mohamad played an important part pushing for the creation of the Special Cabinet Committee on MA63.
} 
agenda, depending on the balance of political leverage of East Malaysian states versus the opposition. ${ }^{34}$

Opinions such as the following, which recognize the weight of PH's efforts as well as stalling or resisting tactics among adversaries, were echoed in focus group discussions with former and current senior state civil servants in Sabah:

When late Liew was appointed as the minister in charge of Law under previous Pakatan Harapan government, it was a clear sign that Pakatan Harapan federal was serious about reform-restoring East Malaysian rights, but then opposition parties in Sabah failed to voice out a collective bipartisan support for Liew to carry out his work. $^{35}$

Liew Vui Keong as the de facto Law Minister was instrumental to the formation of a Special Cabinet Committee on Malaysia Agreement 1963. ${ }^{36}$ This committee, ${ }^{37}$ headed by Mahathir, also included the two

${ }^{34}$ Tricia Yeoh, Federal-State Relations under the Pakatan Harapan Government, Trends in Southeast Asia, no. 12/2020 (Singapore: ISEAS - Yusof Ishak Institute, 2020).

${ }^{35}$ Focus group discussion, 19 December 2020.

${ }^{36}$ Allison Lai, "Liew Reveals the Composition of Steering Committee of Special Cabinet Committee on MA63", The Star, 10 October 2018, https://www. thestar.com.my/news/nation/2018/10/10/liew-reveals-composition-of-steeringcommittee-on-ma63 (accessed 20 November 2020).

37 The composition of Special Cabinet Committee on MA63 under PH was as follows: Tun Dr Mahathir Mohammad (Prime Minister), Shafie Apdal (Chief Minister of Sabah), Abang Johari Tun Openg (Chief Minister of Sarawak), Liew Vui Keong (Minister-in-Charge of Law), Lim Guan Eng (Finance Minister), Mohamed Azmin Ali (Economic Affairs Minister), Gobind Singh Deo (Communication and Multimedia Minister), Saifuddin Abdullah (Foreign Minister), Baru Bian (Works Minister), Darell Leiking (International Trade and Industry Minister), Anthony Loke Siew Fook (Transport Minister), Dr Ismail Bakar (Chief Secretary), David Wong Dah Wah (Chief Justice of Sabah and Sarawak), Tommy Thomas (Attorney General), Dr Shad Saleem Faruqi (Constitutional Expert), Zaleha Rose Pandin (Sabah Attorney General), and Talat Mahmood Abdul Rashid (Sarawak Attorney General). 
Chief Ministers of Sabah and Sarawak. It was created in October 2018 and proceeded with its work from late 2018 through 2019. On December 2019, Deputy Minister in the Prime Minister Department, Hanipa Maidin, stated in parliament that the Special Cabinet Committee had resolved seventeen out of twenty-one issues related to MA63.

The seventeen resolved issues pertaining to MA 63 were:

(i) Claims to export duties for logs and forest products in Sabah;

(ii) Regulation of gas and electricity distribution in Sarawak and Sabah;

(iii) Implementation of federal works in Sarawak and Sabah;

(iv) Labour force in Sarawak and Sabah;

(v) The states' authority over health issues in Sarawak and Sabah;

(vi) Administration of Sipadan and Ligitan Islands in Sabah;

(vii) Agricultural and forestry issues;

(viii) Federal financial obligations under the joint list;

(ix) Review of special gifts;

(x) Fishing, inshore and offshore fisheries;

(xi) Ownership given to federal land in states;

(xii) Legal authority on environment and tourism;

(xiii) Article 112 of the Federal Constitution (Increase in Employment);

(xiv) Delegation of power to Sabah and Sarawak courts;

(xv) Jurisdiction of chief judge of Sabah and Sarawak, autonomous administration of Sabah and Sarawak courts, and experience of Borneo judges to hear appeal cases filed in a Borneo state;

(xvi) Judicial Commissioner appointment; and

(xvii) Stamp duties imposed on transfer instruments, charges, lease of land under Sarawak and Sabah land ordinance. ${ }^{38}$

Only four areas needed further deliberations. These were: oil royalty and petroleum cash payments; jurisdiction over oil minerals and oil fields;

${ }^{38}$ Bernama, "MA63: 17 Issues Resolved, 4 Still Being Discussed", New Strait Times Online, 10 December 2019, https://www.nst.com.my/news/ nation/2019/12/546647/ma63-17-issues-resolved-4-still-being-discussed (accessed on 20 November 2020). 
the Territorial Sea Act 2012; and the states' rights over the continental shelf. ${ }^{39}$

Sabah leaders also played a crucial part in the PH federal government's attempt to amend Article 1(2) of the Malaysian Federal Constitution to restore both Sabah's and Sarawak's position in the Malaysian Federation. The intention of the bill was to restore the two states' status as "equal partners" with Malaya by restoring Article 1(2) to its original form in 1963.

The proposed constitutional bill needed 148 votes to pass the floor test in the lower house of parliament. Given that the ruling PH coalition had 138 MPs, the bill required just ten votes from opposition parties. When the bill was put forward for a floor test in April 2019 in the lower house of Malaysian parliament, it failed to get a two-thirds majority. Some fifty-nine MPs, mainly from the opposition UMNO and GPS, abstained. ${ }^{40}$

Many opposition members of parliament, including those from Sabah and Sarawak argued that the proposed constitution amendment was just a cosmetic change that would not restore East Malaysian rights. ${ }^{41}$ In fact, members from GPS argued the phrase "pursuant to Malaysia Agreement 1963 " should be included and called for a further discussion in the Special Select Committee. But others believed that the action by GPS was purely a strategic ploy to maintain momentum on the issue of East Malaysian rights in a run-up to the Sarawak state election.

In this author's focus group discussion with members of the ruling PBB in Sarawak, they pointed out that the main reason behind GPS's

\footnotetext{
${ }^{39}$ Ibid.

40 Adam Aziz, "No Two-Thirds Majority for Bill to Make Sabah, Sarawak Equal Partners", The Edge Markets, 9 April 2019, https://web.archive.org/ web/20190410021305/https://www.theedgemarkets.com/article/no-twothirdsmajority-bill-make-sabah-sarawak-equal-partners (accessed 2 February 2021).

${ }^{41}$ Wong King Wei, "MA63 Amendments a Big Step By Harapan-Opponents by Vested Interests”, Malaysiakini.com, 6 April 2019, https://www.malaysiakini. com/news/471125 (accessed 20 December 2020).
} 
decision to not support the bill was not because of the problem with "wording". There was fear within the ruling GPS that Sarawak PH would get tremendous political mileage if the constitutional amendments were passed. This, in turn, would weaken the PBB's position in promoting "Sarawakian Nationalism" as well as diminish its support. ${ }^{42}$

But for senior civil servants from East Malaysia who had engaged in various stages of this proposed constitutional amendment bill, the failure of the bill was purely a selfish and betrayal act by politicians. These senior civil servants stated that:

the proposed constitution amendment bill Article 1(2) is to restore to its original form, in 1976 an amendment was done to this particular article, more importantly all the East Malaysian MPs have been briefed by this particular amendment and voting against the bill by East Malaysian politicians was purely an act of betrayal $^{43}$

East Malaysian politicians in the former PH federal cabinet such as former work minister Baru Bian believe that East Malaysian politicians in the federal cabinet under PH rule have done justice by undertaking reforms, including the restoration of East Malaysia's special position even though this did not materialize. ${ }^{44}$

\footnotetext{
${ }^{42}$ Focus group discussion, 19 February 2021, with members of PBB, Sarawak.

${ }^{43}$ Focus group discussion, 19 December 2020, with senior civil servants.

44 According to Baru Bian, the former minister in the Pakatan Harapan government, when $\mathrm{PH}$ took over the federal government from $\mathrm{BN}$, the restoration of East Malaysian rights was one of its key priorities. He added: "Under $\mathrm{PH}$, Cabinet Steering Committee and the Technical Committee were duly formed. We resolved most of the issues identified except for 4 main issues outstanding then which were supposed to be dealt with by the PM and the two state CMs. Federal Ministers were then able to relate with the State Leaders. I myself had no problem. Under PN I don't see anything seriously discussed except a new Committee was formed and nothing was heard about what came from that Committee.” (Interview conducted with YB Baru Bian, 26 January 2021.)
} 


\section{PERIKATAN NASIONAL AND MA63's FUTURE PROSPECTS}

A new coalition called Perikatan Nasional (PN, or National Alliance) headed by Muhyiddin Yassin as the Prime Minister was formed. ${ }^{45}$ It comprised defectors from $\mathrm{PH}$ as well as members of former opposition parties such as UMNO, PAS and GPS.

When PN took over, Maximus Ongkili, the Minister in the Prime Minister Department (Sabah and Sarawak affair), was given the task to revive the Special Cabinet Committee on MA63. In fact, on 13 March 2020, Ongkili promised that within six months the issues related to MA63 would be resolved. He further noted that PN under Muhyiddin Yassin was committed to resolving all the issues, including restoring Sabah's and Sarawak's status as equal partners with Peninsular Malaysia. ${ }^{46}$

But, in July 2020, Deputy Minister in the Prime Minister Department, Hanifah Hajar Taib, announced that the Special Cabinet Committee report on MA63 carried out under PH would not be available to the public

\footnotetext{
${ }^{45}$ GPS played an important part in the infamous "Sheraton move" that brought about the creation of PN and the appointment of Muhyiddin Yassin as the Prime Minister. Abang Johari attended the informal talks with PH defectors, UMNO, and PAS. To handle the matter smoothly, the chief whip of GPS was stationed in Kuala Lumpur to facilitate the change of government in Putrajaya. It is fair to say that without GPS's support for PN, it would have been impossible for $\mathrm{PH}$ to collapse. For GPS, the change in Putrajaya from PH to PN was necessary to stop the growing influence of Sarawak PH. In Sabah, the change from PH to PN has drastically changed the political landscape of the state. The Warisan$\mathrm{PH}$ coalition was under constant pressure to change its allegiance to the newly created PN federal government. The failed political coup staged by Musa Aman and supported by the PN federal government forced Shafie Apdal to dissolve the state assembly in July 2020 for an unprecedented state election. The outcome of the state election saw the newly created Gabungan Rakyat Sabah under Prime Minister Muhyiddin Yassin narrowly defeat the incumbent Warisan plus coalition.

${ }^{46}$ Malaysian Reserve, "Ongkili Hopes to See MA63 Issues Solved in 6 Months", 13 March 2020, https://themalaysianreserve.com/2020/03/13/ongkili-hopes-tosee-ma63-issues-solved-in-6-months/ (accessed 12 January 2021).
} 
since it had been classified under the Official Secrets Act 1972. ${ }^{47}$ This prompted politicians and political activists in East Malaysia to question the direction of the PN government regarding their previous promises.

Later, on 23 November 2020, Ongkili announced that a special panel on MA63 would convene on 30 November 2020 and would be chaired by Prime Minister Muhyiddin Yassin. He also announced that the major issues to be discussed were: the proposed amendment to Article 1(2) in the Federal Constitution; issues related to the twenty-one points which have been discussed under the previous PH government; and the devolution of power to Sabah and Sarawak courts. ${ }^{48}$ Since then, however, there has been no clear progress on the issues related to MA63, leading many to regard the PN government as reluctant to devolve more autonomous powers to Sabah and Sarawak.

Information gathered from the fieldwork points to two important scenarios regarding the future of East Malaysian rights under PN. The first scenario is that PN will not commit on the issue of restoring East Malaysia's special position, but will instead focus on generously disbursing development funds in East Malaysia under the current State of Emergency. The second possible scenario is that limited discussions will be held on the issue and future of East Malaysia's special position, with the further prospect that if PN wins the next general election, a newly created second deputy prime minister position will be filled by someone from East Malaysia.

The first scenario suggests that PN will not conduct any serious negotiation on East Malaysian prerogatives. Sabah and Sarawak will be compensated with more generous development funding that will

\footnotetext{
${ }^{47}$ Bernama, "MA63: No Need to Make Final Report Public_-Deputy Minister", Malaysiakini.com, 28 July 2020, https://www.malaysiakini.com/news/536466 (accessed 21 January 2020).

${ }^{48}$ Bernama, "Ongkili: Special Council on MA 63 to Convene First Meeting on Nov 30", New Strait Times, 23 November 2020, https:/www.nst.com.my/news/ nation/2020/11/643671/ongkili-special-council-ma63-convene-first-meetingnov-30 (accessed 3 January 2021).
} 
be channelled to friendly partners such as GPS and Gabungan Rakyat Sabah (GRS). Moreover, more positions in the federal government and government-linked companies (GLCs) will be allocated to East Malaysian political elites in return for their support. The main aim of PN dominated by BERSATU is to prepare for the next general election. The COVID-19 situation and accompanying state of emergency has given the national administration space to galvanize support.

The outcome of the 2020 Sabah state election has made the PN leadership realize that GRS won the state election mainly on promises to bring more development to Sabah. This is unlike the previous incumbent Sabah state government under Parti Warisan, which was focused on the restoration of East Malaysia rights. The unexpected win for GRS in the Sabah state election made the PN leadership realize that funding for development is sufficient to secure the support of East Malaysian political elites. ${ }^{49}$

The civil servants that I spoke with assert that:

Yes, the PM promised to continue with reforms when he visited Sibu in 2020, but we think the election victory for Gabungan Rakyat Sabah have changed ... if you look carefully in the Sabah state election, Warisan-Plus used the 21 points as an election campaign tool and I don't think Perikatan Nasional wants to be part of that now. ${ }^{50}$

In fact, Muhyiddin Yassin recently announced a RM4 billion development fund for Sarawak, and at the same time argued that PN did not have a two-thirds majority in the federal parliament to advance East Malaysian rights. Moreover, the Prime Minister requested the ruling GPS headed by Abang Johari to continue the state coalition government's support to PN to help them win the next Malaysian general election. This is to ensure

\footnotetext{
${ }^{49}$ Focus group discussion with BERSATU division leaders.

${ }^{50}$ Focus group discussion, 19 December 2020.
} 
that PN obtains the required number in the federal government to restore East Malaysia's special position. ${ }^{51}$

In addition, PN needs Malay support in order to be relevant in Malaysian politics, and supporting East Malaysian rights is not a politically astute tactic at the moment. Since taking over power from PH, PN has created a special bond with the Islamic Party, PAS. In fact, PN has managed to split PAS from the Muafakat Nasional coalition created between UMNO and PAS. In order to face the next Malaysian general election, the PN federal government headed by BERSATU urgently needs the support of rural Malays. Consequently, PN must demonstrate that it is able to safeguard Malay interests more than UMNO. For instance, when the Malaysian Federal Court allowed a petition by East Malaysian Christians to use the word Allah in church, PN immediately filed an appeal although many East Malaysian political elites requested the federal government to allow closure of the issue and not lodge an appeal.

The second scenario is that some minor discussion will be conducted with East Malaysian political elites in the new Special Cabinet Committee which was created last December. The scope of the initial Special Committee will be redefined to suit the federal government's current interests. This is possible if PN continues to rule the federal government for the full term, with the backing of East Malaysians once the Emergency is lifted in August 2021.

To regain the confidence of East Malaysian political elites, there is a possibility that $\mathrm{PN}$ will offer one deputy prime ministerial post to someone from Sabah or Sarawak. In fact, this strategy is not new, as other political parties such as UMNO have mulled over this idea since the party lost in the last general election. The deputy prime ministerial post will be a replacement for a scaled-down negotiation on East Malaysian issues. $^{52}$

\footnotetext{
${ }^{51}$ Sulok Tawie, "Muhyiddin Promises Sarawakians Priority in Developing Their Interior, RM4.5b Funds under 12MP”, Malay Mail, 1 April 2021, https://www. malaymail.com/news/malaysia/2021/04/01/muhyiddin-promises-sarawakianspriority-in-developing-their-interior-rm4.5b/1963105 (accessed 4 April 2021).

${ }^{52}$ Interview conducted with BERSATU Sabah Division Leader, 7 April 2021.
} 
Perikatan Nasional headed by BERSATU is increasingly seen as a replacement for UMNO in East Malaysia. In fact, BERSATU can make East Malaysia a "fixed deposit" state in terms of political support for the PN federal government. In Sabah, since BERSATU took over the state government under the GRS in 2020, the party managed to gain the support from close rivals in Sabah-UMNO. While currently, at the federal level, the relation between BERSATU and UMNO is unpredictable, nonetheless at the Sabah state level, it is soaring. There is a possibility that UMNO Sabah will merge with BERSATU in order to strengthen the Muslim-bumiputra coalition in Sabah.

In Sarawak, BERSATU is currently lobbying the ruling GPS to contest in the next Sarawak state election. There is a possibility that the ruling GPS headed by Chief Minister Abang Johari will pledge total loyalty to the PN federal government in order to prevent BERSATU from contesting in the next Sarawak state election.

Moreover, the silence from East Malaysian political leaders has further created uncertainty regarding the proposed reforms. The state governments of Sabah and Sarawak are now very much part of the PN federal government, but coordinated efforts from these states were largely missing on the MA63.

In Sabah, since GRS took over the state government from Warisan, it has maintained a low profile on the issues related to East Malaysia's special position. In fact, Bandar Kuching's Kelvin Yii urged the federal and state lawmakers from East Malaysia to take heed:

Let us not repeat the mistake of 1974 and 1976 where our rights were surrendered purely due to "following instructions" without input from the people of Sabah and Sarawak who would ultimately feel the effects of that decision. ${ }^{53}$

${ }^{53}$ Kelvin Yii, "More Transparency Needed from Govt on Sabah and Sarawak Rights", Malaysiakini.com, 11 August 2020, https://www.malaysiakini.com/ columns/538245 (accessed 12 January 2020). 
East Malaysian regional parties' priorities are frequently changing with the change in the federal government. Political power and positions have diluted the demand for a greater political independence from Putrajaya among the East Malaysian political elites. Moreover, there is no bipartisan support among these groups on the issues pertaining to East Malaysian special position. Baru Bian, the former minister stated:

East Malaysian MPs failed to apply bipartisanship when it comes to common issues pertaining to EM rights because they are not sincere in resolving these issues. They politicized these issues and want to be credited for fighting for these issues. They want some political mileage from it and are therefore unable to agree when opportunity to resolve them arises, e.g., the proposed amendment to Article 1(2) of the Federal Constitution. ${ }^{54}$

But the political elites from the two East Malaysian states are aware that pushing for greater rights under the current state of emergency will fail to gain traction, and may backfire if such campaigns are seen as taking precedence over immediate health and socioeconomic concerns.

Moreover, although PN is widely viewed as a fragile political coalition, it has emerged as a nimble political entity that effectively induces allegiance and deploys tools of power, with scant regard for democratic procedure. This has enabled it to attract political elites from across the spectrum including those from opposition parties, and to forestall efforts to challenge Muhyiddin's majority. PN's flexibility in political alignment made East Malaysia's political elites wary. Any miscalculation by PN will lead to them losing political power, position, and influence. For this reason, GPS will remain with PN and proceed with the state elections, which will consolidate its position as the defender of Sarawak interests.

\footnotetext{
${ }^{54}$ Interview conducted with YB Baru Bian, 26 January 2021.
} 


\section{CONCLUSION}

This study has traced the major political developments in East Malaysia under the PH and PN federal governments. It argues that the sudden collapse of $\mathrm{PH}$ and the rise of PN government under Prime Minister Muhyiddin Yassin have created uncertainty regarding the proposed devolution of power to the two East Malaysian states.

Under the previous PH federal government, a Special Cabinet Committee was created to oversee the restoration of East Malaysia's special position. The Committee managed to solve seventeen out of twenty-one matters of concern on East Malaysia. Moreover, the previous PH government also mooted a constitutional change to Article 1(2) in the Malaysian Constitution to restore East Malaysian states as equal partners. However, it was unable to secure the required two-thirds majority in parliament.

When PN took over the federal government in early 2020, Prime Minister Muhyiddin promised a devolution of power to the two East Malaysian states. But later, the PN federal government announced that the final report on the proposed devolution to East Malaysia prepared by the Special Committee would be listed under the Official Secrets Act.

This action sparked concern that the current federal government is not serious about the devolution of power to East Malaysian states. More importantly, Sabah and Sarawak are currently administrated by federalfriendly state governments.

In this context, the PN government realize that, based on the outcome of the 2020 Sabah state election, issues related to developmentalism are more important for voters than the restoration of East Malaysia's special position. Moreover, the COVID-19 situation has given PN an upper hand to declare a State of Emergency, and enabled it to consolidate political support from various factions.

Going forward, the politics related to MA63 reforms will remain highly salient in Sabah and Sarawak. But the agenda and related issues will be dealt with by narrowing the scope significantly and focusing more on symbolic and developmental issues for East Malaysia. 